\title{
Exploring a novel edible mushroom Ramaria subalpina: Chemical characterization and Antioxidant activity
}

\author{
Krishnendu Acharya, ${ }^{1 *}$ Kanad Das, ${ }^{2}$ Soumitra Paloi, ${ }^{1}$ Arun Kumar Dutta, ${ }^{1}$ Manoj Emanuel Hembrom, ${ }^{3}$ Somanjana \\ Khatua, ${ }^{1}$ and Arvind Parihar ${ }^{2}$
}

\section{Krishnendu Acharya, ${ }^{1 *}$ Kanad Das, ${ }^{2}$ Soumitra Paloi, ${ }^{1}$ Arun Kumar Dutta, ${ }^{1}$ Manoj Emanuel Hem- brom, ${ }^{3}$ Somanjana Khatua, ${ }^{1}$ and Arvind Parihar ${ }^{2}$}

'Department of Botany, Molecular and Applied Mycology and Plant Pathology Laboratory, University of Calcutta, 35, Ballygunge Circular Road, Kolkata-700019, West Bengal, INDIA.

${ }^{2}$ Cryptogamic Unit, Botanical Survey of India, P.O.-Botanic Garden, Howrah-711103, INDIA.

${ }^{3}$ Central National Herbarium, Botanical Survey of India, Central National Herbarium, P. O.-Botanic Garden, Howrah - 711103, INDIA.

\section{Correspondence}

Krishnendu Acharya ${ }^{1 *}$, Department of Botany, University of Calcutta, Taraknath Siksha Prangan, 35 Ballygunge Circular Road,

Kolkata- 700 019, INDIA.

Phone: (0091) (033) 24753681

E-mail: krish_paper@yahoo.com

History

- Submission Date: 20-08-2016

- Review completed: 13-09-2016;

- Accepted Date: 20-10-2016.

DOI : 10.5530/pj.2017.1.6

Article Available online

http://www.phcogj.com/v9/i1

\section{Copyright}

(C) 2016 Phcog.Net. This is an openaccess article distributed under the terms of the Creative Commons Attribution 4.0 International license.

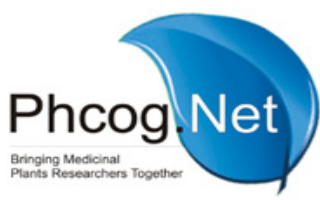

\begin{abstract}
Background: During macrofungal inventorisation from an unexplored subalpine forest of Sikkim Himalayas, a new edible mushroom, Ramaria subalpina was found and documented in consultation with the forest dwellers. Objective: The aim of the present study was to understand the antioxidative potentiality and bioactive constituents of a novel taxon, Ramaria subalpina, that is highly prized by the ethnic people of subalpine Sikkim Himalayas, India, for its flavor, texture and gastronomic delicacy since time immemorial. Methods: Chemical composition and antioxidant properties of methanolic extract of dried basidiocarps were assessed using HPLC and several in vitro assay systems. Results: Methanolic extract had phenolics in highest amount, among which pyrrogallol was identified. It also showed potent antioxidant activity. Conclusion: The present study suggests that Ramaria subalpina has strong medicinal prospects. This novel mushroom can safely be added to the world's edible mushrooms list.
\end{abstract}

Key words: Antioxidant activity, DPPH, Ferrous ion chelating, HPLC, India.

\section{INTRODUCTION}

Rural communities of India, utilize certain local wild mushrooms for food and medicine, but such indigenous knowledge is either not reported or poorly documented and unsystematically recorded. Claims of their efficacy to be considered as food or medicine need to be scientifically verified prior to their acceptance. It is therefore necessary to know and correctly identify these mushroom species, used by the locals as food or medicine. For this said purpose, the authors are engaged to unveil the hidden macro fungal diversity of the country with an insight to explore their traditional knowledge that is specifically cryptic to the local communities. ${ }^{1-3}$

Choice of food with their myriad usages and cuisine are the signature of cultural, regional and national identity. They are key elements for the dietary patterns in different countries and are consequently important in accurately estimating population dietary intakes. However, throughout Europe, traditional foods are threatened with extinction due to altered lifestyles, and nutritional information of these foods is missing from most current food composition databases., ${ }^{4,5}$ In recent days, consumers are looking for new foods with various organoleptic characteristics for their daily lunch basket. Traditional foods such as mushrooms might fulfill this demand, as they are quite rich in carbohydrate, fiber and protein with all essential amino acids and have a low fat content. ${ }^{6}$ In a general approxi- mation, the fruit body of a mushroom contain about $56.8 \%$ carbohydrate, $25.0 \%$ protein, $5.7 \%$ fat and $12.5 \%$ ash on a dry weight basis. ${ }^{7}$ In addition, edible mushrooms are also rich in various polyphenolic compounds that are recognized as an excellent antioxidant due to their ability to scavenge free radicals by single-electron transfer. The enhancement of antioxidant systems for the prevention of cellular oxidative damage via consumption of antioxidant rich foods is of great interest. ${ }^{8}$

In search of wild edible mushrooms (WEM) that are commonly prized by the local forest dwellers across the country, we came across quite a number of mushroom taxa that has been previously identified and reported therein. ${ }^{3,9,10}$ Ramaria subalpina K. Das \& K. Acharya [commonly called as 'thokrechyau' (Nepali; 'thokre' = in bunch and 'chyau' = mushroom)], a newly described taxa, ${ }^{10}$ traditionally consumed as an edible mushroom (Figure 1A) by the ethnic people of subalpine Sikkim Himalaya for its flavor, texture and gastronomic delicacy since time immemorial was explored to understand its antioxidative potentiality and bioactive constituents.

\section{MATERIALS AND METHODS}

\section{Preparation of methanolic extracts}

Basidiocarps of the collected specimen were cleaned to remove residual compost and dried at a maximum temperature of $45 \pm 3^{\circ} \mathrm{C}$. Dried basidiocarps were

Cite this article : Acharya K, Das K, Paloi S, Dutta AK, Hembrom ME, Khatua S, Parihar A. Exploring a novel edible mushroom Ramaria subalpina: Chemical characterization and Antioxidant activity. Pharmacog J.2017;9(1):30-4. 

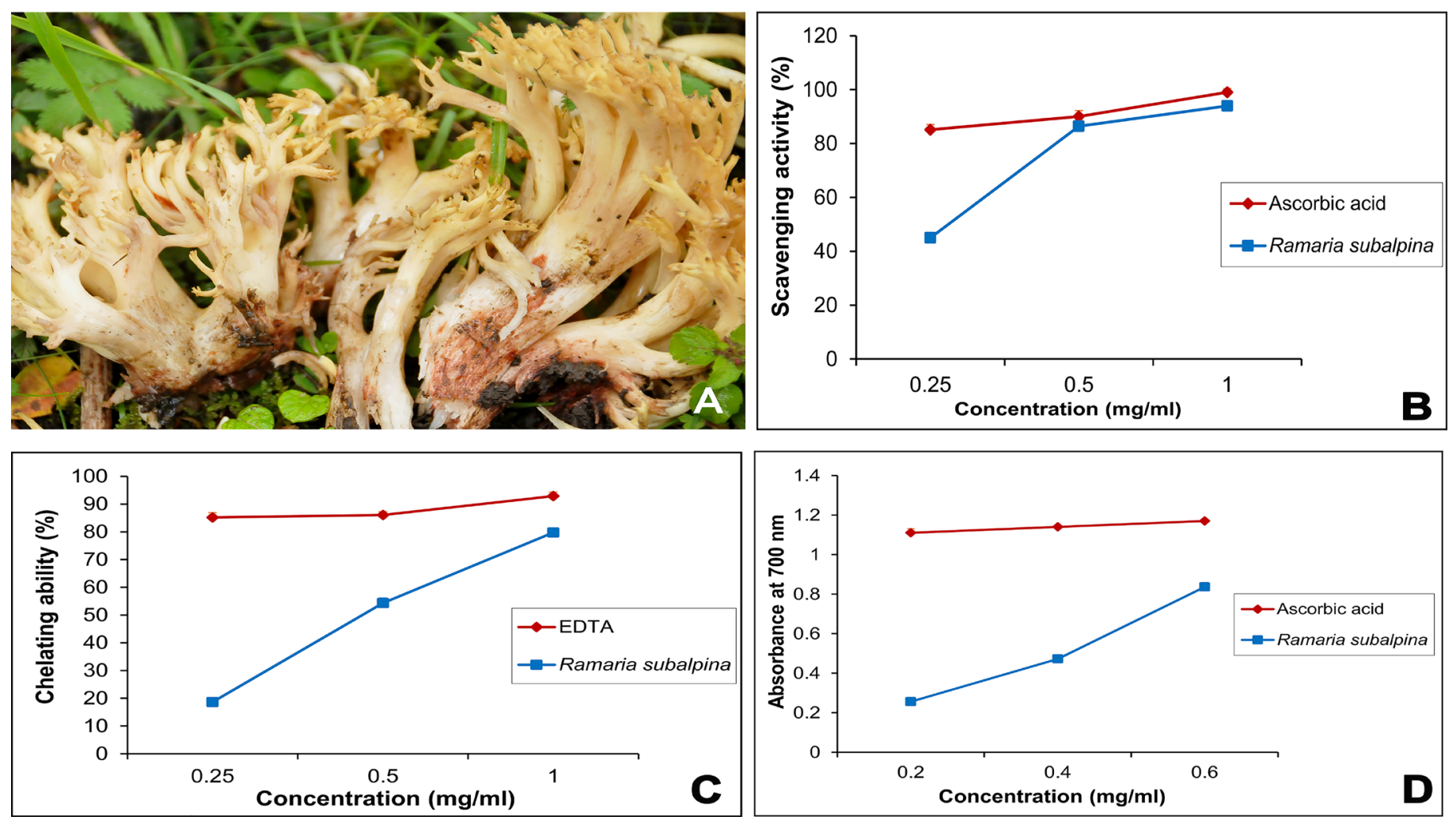

FIGURE 1: Ramaria subalpina (A) Fresh basidiocarps in the field (B) DPPH radical scavenging activity (C) Ferous ion chelating ability (D) Reducing power. Results are the mean \pm SD of three separate experiments, each in triplicate.

ground to obtain fine particles. One gm of the powder was extracted by stirring with $50 \mathrm{ml}$ of methanol for overnight and subsequently separated by Whatman filter paper. The residue was then re-extracted with $30 \mathrm{ml}$ of methanol and the combined methanolic extracts were evaporated at $40^{\circ} \mathrm{C}$ (Rotavapor R3 Buchi, Switzerland) to dryness. The methanolic fraction was stored at $-20^{\circ} \mathrm{C}$ in a dark bottle until analysis, for no more than 1 month. A stock solution of $20 \mathrm{mg} / \mathrm{ml}$ of the fraction was prepared. Successive dilutions were made to evaluate chemical characterization and antioxidant activity. ${ }^{11}$

\section{Chemical composition \\ Determination of total phenolic compound}

Total phenolics were measured using Folin-Ciocalteu reagent. ${ }^{12} 1 \mathrm{ml}$ of methanolic extract was mixed with $1 \mathrm{ml}$ Folin-Ciocalteu reagent and incubated for 3 minutes at room temperature. After incubation, $1 \mathrm{ml}$ of $35 \%$ saturated $\mathrm{Na}_{2} \mathrm{CO}_{3}$ solution was added in the reaction mixture and volume was adjusted to $10 \mathrm{ml}$ with distilled water. The reaction mixture was incubated in dark for $90 \mathrm{~min}$, after which the absorbance was read at $725 \mathrm{~nm}$ by a spectrophotometer. Gallic acid was used as standard. Total phenol content of the sample was expressed as $\mu \mathrm{g}$ of gallic acid equivalent per mg of extract.

\section{Determination of total flavonoid content}

Flavonoid concentration was determined following the method as described by Adebayo et al. ${ }^{13} 1 \mathrm{ml}$ methanolic extract was diluted with $4.3 \mathrm{ml}$ of $80 \%$ aqueous methanol and subsequently, $0.1 \mathrm{ml}$ of $10 \%$ aluminum nitrate and $0.1 \mathrm{ml}$ of $1 \mathrm{M}$ aqueous potassium acetate were added to it. After $40 \mathrm{~min}$ of incubation at room temperature, the absorbance was determined spectrophotometrically at $415 \mathrm{~nm}$. Total flavonoid concentration was calculated using quercetin as standard.

\section{Determination of total ß-carotene and lycopene content}

Total $\mathrm{B}$-carotene and lycopene was determined according to Nagata and Yamashita. ${ }^{14}$ The process, in brief was $100 \mathrm{mg}$ of methanolic extract was vigorously shaken with $10 \mathrm{ml}$ of acetone-hexane mixture (4:6) for $1 \mathrm{~min}$ and absorbance of the mixture was measured at 453, 505 and $663 \mathrm{~nm}$. $B$-carotene and lycopene contents were based on the following equations:

$$
\text { Lycopene }(\mathrm{mg} / 100 \mathrm{ml})=-0.0458 \mathrm{~A} 663+0.372 \mathrm{~A} 505-0.0806 \mathrm{~A} 453
$$

$$
\text { B-carotene }(\mathrm{mg} / 100 \mathrm{ml})=0.216 \mathrm{~A} 663-0.304 \mathrm{~A} 505+0.452 \mathrm{~A} 453
$$

\section{Determination of ascorbic acid content}

Ascorbic acid was determined by titration as described by Rekha et al. ${ }^{15}$ With little modification. Standard ascorbic acid $(0.1 \mathrm{mg} / \mathrm{ml})$ was taken in a conical flask and made up to $10 \mathrm{ml}$ by $0.6 \%$ oxalic acid. It was titrated with a dye 2,6-dichlorophenol indophenol (21 mg sodium bicarbonate and $26 \mathrm{mg}$ of dye in $100 \mathrm{ml}$ water). The amount of dye consumed (V1 ml) is equivalent to the amount of ascorbic acid. The methanolic extract ( $\mathrm{w} \mu \mathrm{g} / \mathrm{ml}$ ) was similarly titrated with the dye (V2 $\mathrm{ml}$ ). The amount of ascorbic acid was calculated using the formula-

$$
\text { Ascorbic acid }(\mu \mathrm{g} / \mathrm{mg})=(\{(10 \mu \mathrm{g} / \mathrm{V} 1 \mathrm{ml}) \times \mathrm{V} 2 \mathrm{ml}\} \times \mathrm{w} \mu \mathrm{g}) \times 1000
$$

\section{Determination of phenolic profile by HPLC}

For quantitative analysis of phenolic compounds, a 3-level calibration curve was obtained by injection of known concentrations $(10-50 \mu \mathrm{g} / \mathrm{ml})$ of eleven standard compounds: gallic acid $(\mathrm{y}=34.773 \mathrm{x}-9.2238$; $\left.\mathrm{R}^{2}=0.9991\right), p$-hydroxybenzoic acid $\left(\mathrm{y}=45.79 \mathrm{x}-7.3583 ; \mathrm{R}^{2}=0.9995\right)$ chlorogenic acid $\left(y=13.776 \mathrm{x}-2.9025 ; \mathrm{R}^{2}=0.9993\right)$, vanillic acid $\left(y=19.225 x+0.2588 ; R^{2}=0.9994\right), p$-coumaric acid $(y=49.773 x-10.541$; $\left.\mathrm{R}^{2}=0.9994\right)$, ferulic acid $\left(\mathrm{y}=30.425 \mathrm{x}-2.8188 ; \mathrm{R}^{2}=0.9995\right)$, myricetin $\left(y=5.0676 x-6.0375 ; R^{2}=0.9937\right)$, salicylic acid $(y=4.4974 x-0.4763$; $\left.\mathrm{R}^{2}=0.9994\right)$, quercetin $\left(\mathrm{y}=5.2478 \mathrm{x}-5.9763 ; \mathrm{R}^{2}=0.9954\right)$, cinnamic acid 
$\left(y=108.07 x-111.55 ; R^{2}=0.9979\right)$ and pyrogallol $(y=10.8 x+0.3333 ;$ $\left.\mathrm{R}^{2}=0.9999\right)$.

For HPLC analysis, $10 \mathrm{mg}$ dried extract was dissolved in $1 \mathrm{~mL}$ of HPLC grade methanol and then was filtered through a $0.2 \mu \mathrm{m}$ membrane, 20 $\mu \mathrm{L}$ of the filtrate was analyzed by HPLC (Agilent, USA). Separation was performed with Agilent Eclipse plus $\mathrm{C}_{18}$ column $(100 \times 4.6 \mathrm{~mm}, 3.5 \mu \mathrm{m})$ using a flow rate of $0.8 \mathrm{~mL} / \mathrm{min}$ at room temperature. The mobile phase consisted of eluent A (acetonitrile) and eluent B (aqueous phosphoric acid solution, $0.1 \% \mathrm{v} / \mathrm{v}$ ). Elution was carried out by using a gradient procedure: $0-2 \mathrm{~min}, 5 \% \mathrm{~A} ; 5-10 \mathrm{~min}, 15 \% \mathrm{~A} ; 10-15 \mathrm{~min}, 40 \% \mathrm{~A} ; 15-20 \mathrm{~min}$, $60 \% \mathrm{~A} ; 20-22 \mathrm{~min}, 90 \% \mathrm{~A}$. The compounds were identified by their UV spectra recorded with diode array detector and retention time of authenticate standards. The results were expressed in $\mu \mathrm{g}$ per $\mathrm{g}$ of extract.

\section{Antioxidant activity of the mushroom fraction Total antioxidant activity}

The total antioxidant capacity was determined as described by Prieto et al. ${ }^{16}$ With little modification. In brief, $0.3 \mathrm{ml}$ of methanolic extract with varying concentration $(0.1-1 \mathrm{mg} / \mathrm{ml})$ was added to $3 \mathrm{ml}$ of the reaction mixture $(0.6 \mathrm{M}$ sulphuric acid, $28 \mathrm{mM}$ sodium phosphate and $4 \mathrm{mM}$ ammonium molybdate). The tubes were capped and incubated in a thermal block at $95^{\circ} \mathrm{C}$ for $90 \mathrm{~min}$. After cooling to room temperature, the absorbance of the aqueous solution of each was measured at $695 \mathrm{~nm}$ against a blank. Ascorbic acid was used as standard and the total antioxidant capacity is expressed as equivalents of ascorbic acid.

\section{DPPH radical scavenging activity}

Radical scavenging activity was determined using a DPPH assay as described by Shimada et al..$^{17}$ Various concentrations of the methanolic extract $(0.25,0.5$ and $1 \mathrm{mg} / \mathrm{ml})$ were added to $2 \mathrm{ml}$ of $0.004 \%$ methanol solution of DPPH (w/v). After 30 min incubation at room temperature in dark, the absorbance was read against a methanol blank at $517 \mathrm{~nm}$. $\mathrm{EC}_{50}$ value is the effective concentration at which DPPH radicals were scavenged by $50 \%$. Ascorbic acid was used for standard. The degree of scavenging was calculated by the following equation:

$$
\text { Scavenging effect }(\%)=\{(\mathrm{A} 0-\mathrm{A} 1) / \mathrm{A} 0\} \times 100
$$

$\mathrm{A} 0$ and $\mathrm{A} 1$ were the absorbance of the control and absorbance in presence of sample respectively.

\section{Ferrous ion chelating ability}

Chelating ability was determined according to the method of Dinis et al. ${ }^{18}$ Different concentrations of methanolic extract $(0.25,0.5$ and $1 \mathrm{mg} / \mathrm{ml}$ ) were mixed with $0.1 \mathrm{ml}$ of $2 \mathrm{mM}$ ferrous chloride. The reaction was initiated by addition of $0.2 \mathrm{ml}$ of $5 \mathrm{mM}$ ferrozine. After $10 \mathrm{~min}$ at room temperature, the absorbance of the mixture was determined at $562 \mathrm{~nm}$ against a blank. EDTA was used as positive control. $\mathrm{EC}_{50}$ value is the effective concentration at which ferrous ions were chelated by $50 \%$. The percentage of inhibition of ferrozine- $\mathrm{Fe}^{2+}$ complex formation is given by this formula:

Scavenging effect $(\%)=\{(\mathrm{A} 0-\mathrm{A} 1) / \mathrm{A} 0\} \times 100$

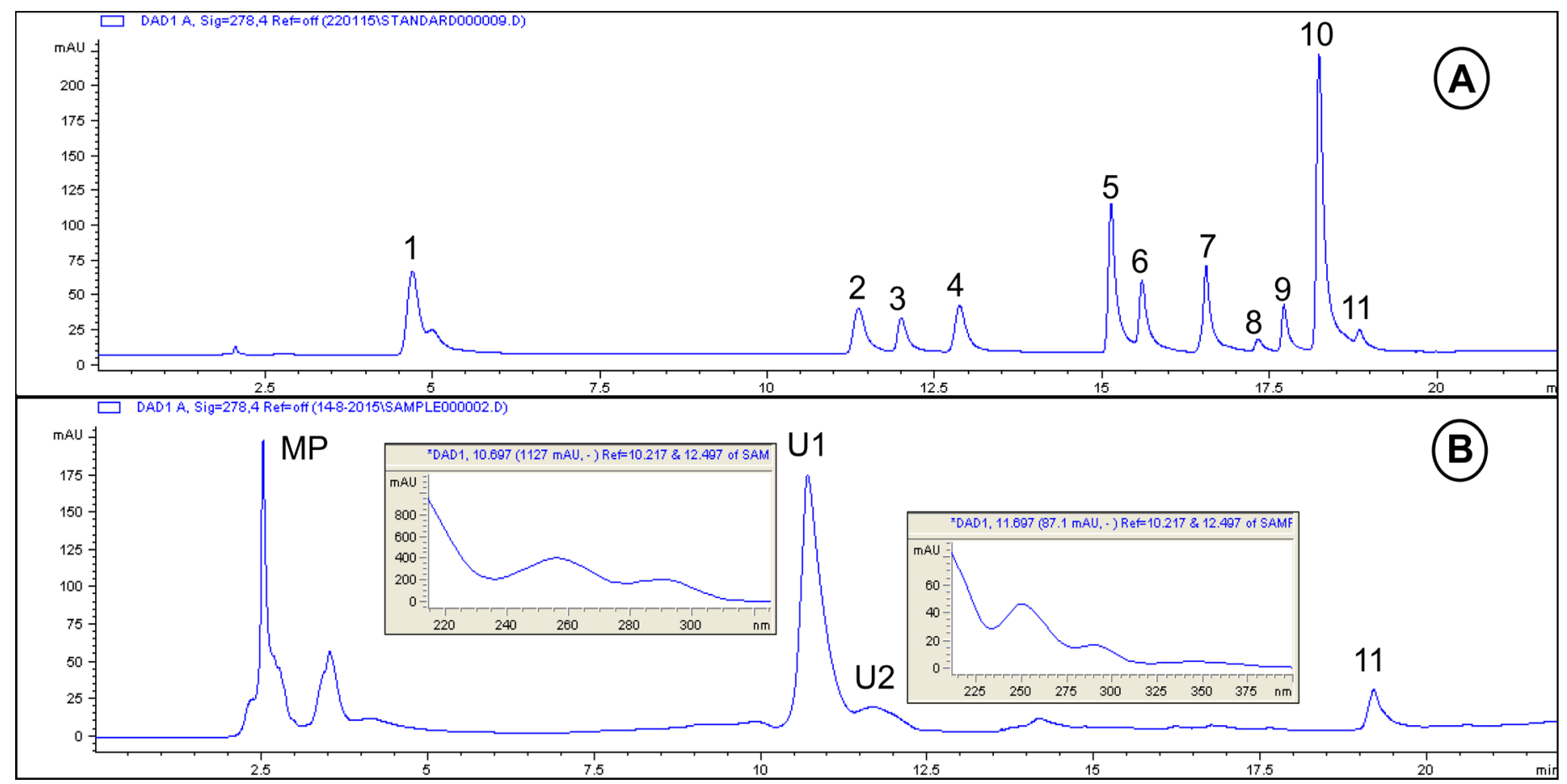

FIGURE 2. HPLC chromatogram of standards and methanolic extract of Ramaria subalpina (A) Standards (B) Phenolic profile of the extract (peaks: MP: mobile phase; 1: gallic acid (RT $4.695 \mathrm{~min}$ ); U1: unidentified peak (RT $10.697 \mathrm{~min}$ ); 2: p-hydroxybenzoic acid (RT 11.357 min); U2: unidentified peak (RT 11.692 $\mathrm{min}$ ); 3: chlorogenic acid (RT $11.997 \mathrm{~min}$ ); 4: vanillic acid (RT $12.867 \mathrm{~min}$ ); 5: p-coumaric acid (RT $15.128 \mathrm{~min}$ ); 6: ferulic acid (RT $15.588 \mathrm{~min}$ ); 7 : myricetin (RT $16.547 \mathrm{~min}$ ); 8: salicylic acid (RT $17.327 \mathrm{~min}) ;$ 9: quercetin (RT $17.711 \mathrm{~min}) ; 10:$ cinnamic acid (RT 18.237 min); 11: pyrogallol (RT $18.837 \mathrm{~min})$.

Table 1: Total phenolic compound, flavonoid, B-carotene, lycopene and ascorbic acid concentrations of the methanolic extract of Ramaria subalpina.

$\begin{array}{ccccc}\begin{array}{c}\text { Total phenolic compound } \\ (\mu \mathrm{g} / \mathrm{mg})\end{array} & \begin{array}{c}\text { Total flavonoid content }(\mu \mathrm{g} / \\ \mathrm{mg})\end{array} & \begin{array}{c}\text { Total B-carotene content } \\ (\mu \mathrm{g} / \mathrm{mg})\end{array} & \begin{array}{c}\text { Total lycopene content }(\mu \mathrm{g} / \\ \mathrm{mg})\end{array} & \begin{array}{c}\text { Ascorbic acid contain }(\mu \mathrm{g} / \\ \mathrm{mg})\end{array} \\ 17.5 \pm 2.5 & 2.5 \pm 0.5 & 0.0239 \pm 0.002 & 0.0122 \pm 0.0016 & 0.083 \pm 0.007\end{array}$

Values are mean \pm SD of three separate experiments each in triplicate. Total phenols are expressed in GAE, and flavonoids are QAE, GAE: Gallic acid equivalent, QAE: Quercetin equivalent. 
$\mathrm{A} 0$ and $\mathrm{A} 1$ were the absorbance of the control and absorbance in presence of sample respectively.

\section{Determination of reducing power}

The reducing power of the methanolic extract was determined according to the method of Oyaizu ${ }^{19}$. Different concentrations of the fraction $(0.2,0.4$ and $0.6 \mathrm{mg} / \mathrm{ml})$ were mixed with phosphate buffer $(2.5 \mathrm{ml}, 0.2 \mathrm{M}$, $\mathrm{pH} 6.6)$ and $2.5 \mathrm{ml}$ of $1 \%$ potassium ferricyanide. The mixture was incubated at $50^{\circ} \mathrm{C}$ for $20 \mathrm{~min}$ and then $2.5 \mathrm{ml}$ of TCA (10\%) was added to the mixture. $2.5 \mathrm{ml}$ of the solution was mixed with distilled water $(2.5 \mathrm{ml})$ and $\mathrm{FeCl}_{3}(0.5 \mathrm{ml}, 0.1 \%)$. The reaction mixture was incubated for $15 \mathrm{~min}$ and absorbance was measured at $700 \mathrm{~nm}$. A higher absorbance indicates a higher reductive capability. Ascorbic acid was used as standard. EC value indicates the effective concentration at which the absorbance was 0.5 for reducing power.

\section{RESULTS AND DISCUSSIONS}

\section{Chemical composition}

Table 1 shows total phenolic compound, flavonoid, B-carotene, lycopene and ascorbic acid concentrations of the methanolic extract of Ramaria subalpina. Total phenolic compound are the major bioactive component found in extract; followed by flavonoid, ascorbic acid, B-carotene, and very small concentration of lycopene. The results revealed that $R$. subalpina had exhibited quite higher amount of total phenolic compound and total flavonoid content as compared to previously reported methanolic extract of edible Ramaria flava (Schaeff.) Quél. which showed $10.51 \pm 0.47 \mu \mathrm{g} / \mathrm{mg}$ of total phenolic compound and $0.51 \pm 0.01 \mu \mathrm{g} / \mathrm{mg}$ of total flavonoid. ${ }^{20}$

HPLC helps to predict phenolic composition of the extract. Figure 2A depicts a typical HPLC chromatogram of eleven phenolic compounds and Figure $2 \mathrm{~B}$ represents HPLC chromatogram of the extract at $10 \mathrm{mg} / \mathrm{ml}$ concentration. The results showed a qualitative profile of extract where 1 peak had been identified. The component in the fraction was found to be pyrrogalol that being present as much as $6.287 \pm 2.473 \mu \mathrm{g} / \mathrm{mg}$ of extract. In addition, two unrecognized phenolic substances $\left(\lambda_{\max }\right.$ in inset) had been detected in the fraction at $10.697 \mathrm{~min}$ and $11.692 \mathrm{~min}$ possessing area of 3966.797 and 587.216 respectively.

\section{Antioxidant activity of the mushroom fraction}

All living organisms are equipped with stress-response systems that regulate the processes of somatic maintenance and repair. ${ }^{21}$ Administration of dietary supplements help to combat oxidative stress and related ailments. Result showed that, $1 \mathrm{mg}$ of Ramaria subalpina was equivalent to $230 \mu \mathrm{g}$ of ascorbic acid. Total antioxidant activity of $R$. subalpina suggests the electron donating capacity, which could act as a radical chain terminator by transforming reactive free radicals into more stable non-reactive products.

DPPH radical scavenging activity can be used to evaluate the antioxidant activity of an extract in a short span of time at room temperature by converting it to 1,1-diphenyl-2-(2,4,6-trinitrophenyl) hydrazine. The amount of yellowing indicates the scavenging potentials of an antioxidant compound. ${ }^{22,23}$ The utilization of stable DPPH radical has the benefit for being unaffected by side reactions, such as enzyme inhibition and metal chelation. ${ }^{24}$ Thus a lower absorbance at $517 \mathrm{~nm}$ indicates a higher radical scavenging activity of the extract. Result indicated that $R$. subalpina exhibited significant radical scavenging activity with $\mathrm{EC}_{50}$ value of $0.3 \pm 0.05 \mathrm{mg} / \mathrm{ml}$ (Figure. 1B). As compared to the previously reported R. flava $(94.78 \pm 0.06 \%$ at $12 \mathrm{mg} / \mathrm{ml})$ and $R$. formosa, ${ }^{20,25}$ the methanolic extract of $R$. subalpina showed grater electron donating capacity.

Ferrous ions are considered to be effective pro-oxidants in food system that increases the risk of free radical damage and cancer. So, moderate ferrous ion chelating abilities would be beneficial for the human life. ${ }^{26,27}$ Sowndhararajan et al. ${ }^{28}$ Reported that chelating agents are helpful as secondary antioxidants, as they decreases the redox potential and thereby stabilises the oxidised forms of metal ions. Figure. 1C reveals that the $R$. subalpina exhibited a marked capacity for iron binding ability of $50 \%$ at a concentration of $0.46 \pm 0.03 \mathrm{mg} / \mathrm{ml}$.

Reducing power of any bioactive compound is directly related to the electron donating capacity and can reduce the oxidized intermediates of lipid peroxidation processes in such a way so that they can act as primary and secondary antioxidants. ${ }^{29,30}$ Presence of reducers causes the conversion of $\mathrm{Fe}^{3+} /$ ferricyanide complex to the ferrous form. Figure $1 \mathrm{D}$ revealed that $R$. subalpina showed reducing power of 0.5 at concentration of $0.44 \pm$ $0.02 \mathrm{mg} / \mathrm{ml}$.

\section{CONCLUSION}

Exploration of the medicinal properties of dried basidiocarps of Ramaria subalpina were subjected for preparation of heat stable phenol rich extract using methanol as solvent system. The fraction showed its potentiality in chelating ferrous ion, DPPH radical scavenging, reducing power and total antioxidant. Total phenols were also found to be the key bioactive component of the extract; followed by flavonoid, ascorbic acid, $ß$-carotene, and lycopene. Molecular phenolic profiling of the extract through HPLC-UV indicated probable existence of pyrrogalol in a higher amount. All these results led to consider the potentiality of the studied mushroom to have a good source of bioactive molecules such as phenolic components for dietary supplements and functional food.

\section{ACKNOWLEDGEMENT}

The authors gratefully acknowledge the Centre of Advanced Study (CAS), University of Calcutta, Kolkata for providing necessary instrumental facilities.

\section{CONFLICT OF INTEREST}

There is no conflict of interest with any financial organization regarding the material discussed in the manuscript.

\section{REFERENCES}

1. Das K Stalpers J, Eberhardt U. A new species of Hericium from Sikkim Himalaya (India). Cryptogamie Mycologie. 2011;32(3):285-93. http://dx.doi. org/10.7872/crym.v32.iss3.2011.285.

2. Dutta AK, Acharya K. Traditional and ethno-medicinal knowledge of mushrooms in West Bengal, India. Asian J Pharm Clin Res. 2014;7:36-41.

3. Khatua S, Dutta AK, Acharya K. Prospecting Russula senecis: a delicacy among the tribes of West Bengal. Peer J. 2015;10;3:e810.

4. Trichopoulou A, Soukara S, Vasilopoulou E. Traditional foods: A science and society perspective. Trend Food Sci Technol. 2007;18(8):420-7. http://dx.doi. org/10.1016/j.tifs.2007.03.007.

5. Trichopoulou A, Vasilopoulou E, Georga K, Soukara S, Dilis V. Traditional foods: Why and how to sustain them. Trend Food Sci Technol. 2006;17(9):498-504. http://dx.doi.org/10.1016/j.tifs.2006.03.005.

6. Gogavekar SS, Rokade SA, Ranveer RC, Ghosh JS, Kalyani DC, Sahoo AK. Important nutritional constituents, flavour components, antioxidant and antibacterial properties of Pleurotus sajor-caju. J Food SciTechnol. 2014;51(8):1483-91. http:// dx.doi.org/10.1007/s13197-012-0656-5; PMid:25114338 PMCid:PMC4108652.

7. Hung PV, Nhi NNY. Nutritional composition and antioxidant capacity of several edible mushrooms grown in the Southern Vietnam. Int Food Res J. $2012 ; 19(2): 611-5$.

8. Kalogeropoulos N, Yanni EA, Koutrotsios G, Aloupi M. Bioactive micro-constituents and antioxidant properties of wild edible mushrooms from the island of Lesvos, Greece. Food Chem Toxicol. 2013;55:378-85. http://dx.doi.org/10.1016/j. fct.2013.01.010; PMid:23354393.

9. Dutta AK, Paloi S, Pradhan P, Acharya K. A new species of Russula (Russulaceae) from India based on morphological and molecular (ITS sequence) data. Turk J Bot. 2015;39(5):850-6. http://dx.doi.org/10.3906/bot-1407-1.

10. Das K, Hembrom ME, Dutta AK, Parihar A, Paloi S, Acharya K. Ramaria subalpina (Gomphaceae): a new edible fungus from India. Phytotaxa. 2016;246(2):137-44. http://dx.doi.org/10.11646/phytotaxa.246.2.5.

11. CuiY, Kim DS, Park KC. Antioxidant effect of Inonotus obliquus. J Ethnopharmacol. 2005;96:79-85. http://dx.doi.org/10.1016/j.jep.2004.08.037; PMid:15588653. 
12. Singleton VL, Rossi Jr JA. Colorimetry of total phenolics with phosphomolybdiophosphotungstic acid reagents. Am J Enol Viticult. 1965;16(3):144-58.

13. Adebayo EA, Oloke JK, Ayandele AA, Adegunlola CO. Phytochemical, antioxidant and antimicrobial assay of mushroom metabolite from Pleurotus pulmonarius -LAU 09 (JF736658). J Microbiol Biotech Res. 2012;2(2):366-74.

14. Nagata M, Yamashita I. Simple method for simultaneous determination of chlorophyll and carotenoids in tomato fruit. J Japan Soc Food Sci Technol. 1992;39(10):925-8. http://dx.doi.org/10.3136/nskkk1962.39.925.

15. Rekha C, Poornima G, Manasa M, Abhipsa V, Pavithra DJ, Vijay HTK, et al. Ascorbic Acid, Total Phenol Content and Antioxidant Activity of Fresh Juices of Four Ripe and Unripe Citrus Fruits. Chem Sci Transac. 2012;1(2):303-10. http://dx.doi. org/10.7598/cst2012.182.

16. Prieto P, Pineda M, Aguilar M. Spectrophotometric quantitation of antioxidant capacity through the formation of phosphomolybdenum complex: specific application to the determination of vitamin E. Anal Biochem. 1999;269(2):337-4. http://dx.doi.org/10.1006/abio.1999.4019; PMid:10222007.

17. Shimada K, Fujikawa K, Yahara K, Nakamura T. Antioxidative properties of Xanthan on the autoxidation of soybean oil in cyclodextrin emulsion. J Agr Food Chem. 1992;40(6):945-8. http://dx.doi.org/10.1021/jf00018a005.

18. Dinis TCP, Mudaira VMC, Alnicida LM. Action of phenolic derivatives (acetaminophen, salicylate, and 5-amino salicylate) as inhibitors of membrane lipid peroxidation and as peroxyl radical scavengers. Arch Biochem Biophys. 1994;315(1):161-9. http://dx.doi.org/10.1006/abbi.1994.1485.

19. Oyaizu M. Studies on products of browning reactions: antioxidative activities of products of browning reaction prepared from glucosamine. Jpn J Nutr. 1986;44:307-15. http://dx.doi.org/10.5264/eiyogakuzashi.44.307.

20. Gursoy N, Sarikurkeu C, Tepe B, Solak MH. Evaluation of antioxidant activities of 3 edible mushrooms: Ramaria flava (Schaef.: Fr.) Qu'el., Rhizopogon roseolus (Corda) T.M. Fries., and Russula delica Fr. Food Sci Biotechnol. 2010;19(3):691-6. http://dx.doi.org/10.1007/s10068-010-0097-8.

21. Sultana B, Anwar F, Przybylski R. Antioxidant activity of phenolic components present in barks of barks of Azadirachta indica, Terminalia arjuna, Acacia nilotica, and Eugenia jambolana Lam. trees. Food Chem. 2007;104(3):1106-14. http:// dx.doi.org/10.1016/j.foodchem.2007.01.019.

22. Liu K, Wang J, Zhao L, Wang Q. Anticancer, antioxidant and antibiotic activities of mushroom Ramaria flava. Food Chem Toxicol. 2013;58:375-80. http://dx.doi. org/10.1016/j.fct.2013.05.001; PMid:23684998.

23. Keles A, Koca I, Gençcelep H. Antioxidant Properties of Wild Edible Mushrooms. J Food Process Technol. 2011;2(6):130-36.

24. Khatua S, Paul S, Acharya K. Mushroom as the Potential Source of New Generation of Antioxidant: A Review. Res J Pharm Tech. 2013;6(5):496-505.

25. Ramesh C, Pattar MG. Antimicrobial properties, antioxidant activity and bioactive compounds from six wild edible mushrooms of Western Ghats of Karnataka, India. Pharmacognosy Res. 2010:2(2):107-12. http://dx.doi.org/10.4103/09748490.62953; PMid:21808550 PMCid:PMC3140106.

26. Halliwell B, Gutteridge JMC, Arumo OI. The deoxyribose method: a simple test tube assay for determination of rate constants for reactions of hydroxyl radical. Anal Biochem. 1987;165(1):215-9. http://dx.doi.org/10.1016/0003 2697(87)90222-3

27. Pal J, Ganguly S, Tahsin KS, Acharya K. In vitro free radical scavenging activity of wild edible mushroom, Pleurotus squarrosulus (Mont.) Singer. Indian J Exp Biol. 2010;47:1210-18.

28. Sowndhararajan K, Joseph JM, Manian S. Antioxidant and Free Radical Scavenging Activities of Indian Acacias: Acacia leucophloea (Roxb.) Willd., Acaciaferruginea Dc., Acacia dealbata Link. and Acacia pennata (L.) Willd. Int J Food Prop. 2013;16(8):1717-29. http://dx.doi.org/10.1080/10942912.2011.604895.

29. Barros L, Joao Ferreira M, Queiros B, Ferreira IC, Baptista P. Total phenol, ascorbic acid, $\beta$-carotene and lycopene in Portuguese wild edible mushroom and their antioxidant acitivities. Food Chem. 2007;103(2):413-9. http://dx.doi. org/10.1016/j.foodchem.2006.07.038.

30. Jayanthi $P$, Lalitha P. Reducing power of the solvent extracts of Eichhornia crassipes (mart.) Solms. Int J Pharm Pharm Sci. 2011;3(3):126-8.

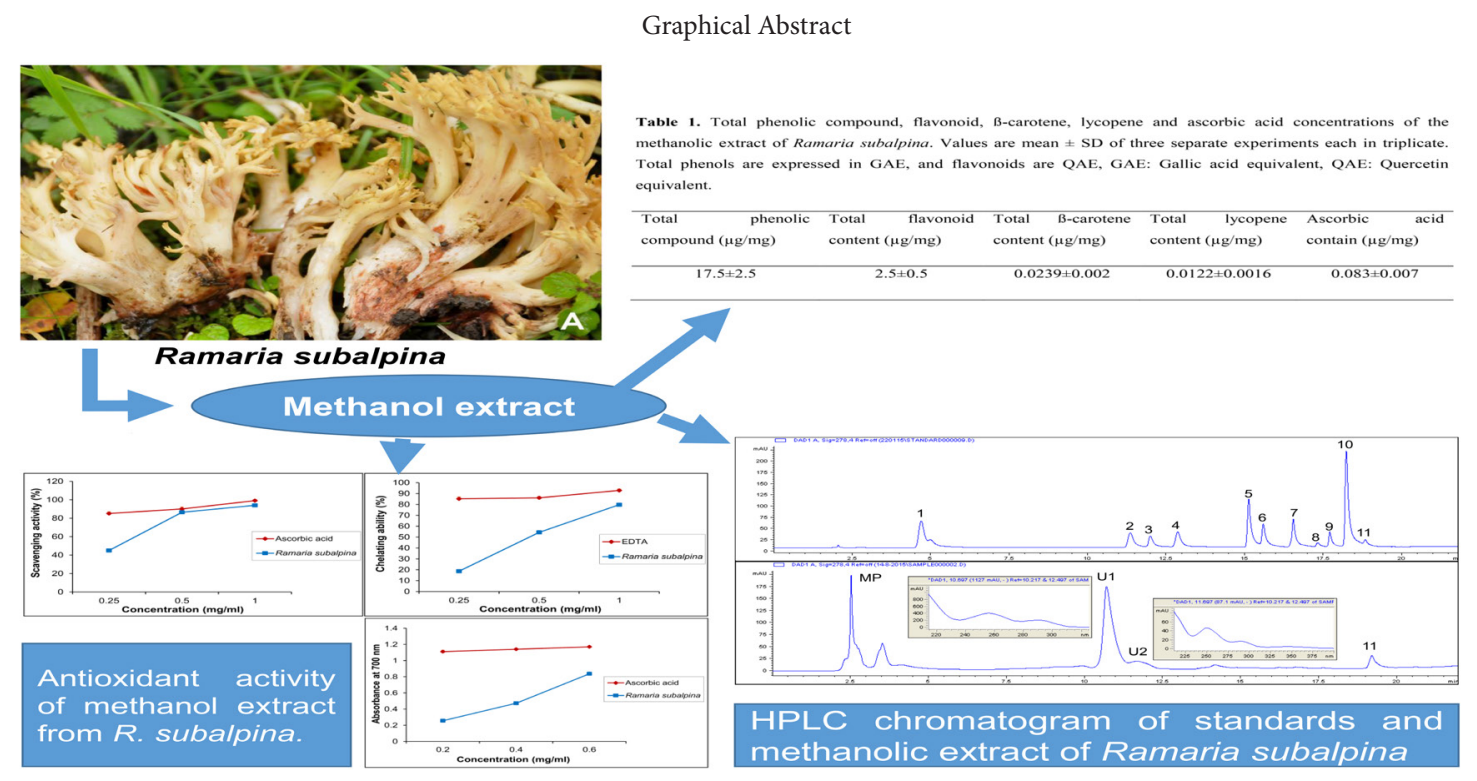

Cite this article : Acharya K, Das K, Paloi S, Dutta AK, Hembrom ME, Khatua S, Parihar A. Exploring a novel edible mushroom Ramaria subalpina: Chemical characterization and Antioxidant activity. Pharmacog J.2017;9(1):30-4. 